\section{West Germany eases law}

\section{Munlch}

SCIENCE organizations breathed a sigh of relief last week in West Germany when the government indicated that it would ease some of the most restrictive provisions in a new 'basic law' to regulate genetic engineering. But the rest of the law may still be harsh enough to accelerate the exodus of pharmaceuticals research and development from the country.

The most welcome change for science organizations, including the Deutsche Forschungsgemeinschaft (DFG) and the Max Planck Society (MPS), was the dropping of a requirement for licensing of individual experiments with genetically modified organisms classified at 'Level 1 ', or 'not dangerous'. DFG and MPS had warned at a closed hearing in Bonn on 25 May that such a licensing procedure could become a bureaucratic nightmare (see Nature 339, 327; 1 June 1989).

The regulations for handling riskier organisms or strains were also relaxed, making a general licensing procedure possible. A central licensing commission (ZKBS) will be called upon to assess experiments within 60 days after an application is submitted.

Representatives of DFG and MPS familiar with the general outlines of the new law continue to object to the regulation of genetic engineering as if it were a dangerous technology. DFG has offered to help the government to draft the allimportant regulations that will be used in applying the law in specific cases.

The effect of the new law on industry will depend largely on the amount of public participation allowed in licensing procedures. In the current version, the licensing of production facilities that use CONSERVATION \section{Japanese traditions kee} Tokyo

JAPAN, the world's largest importer of ivory, has instituted a partial ban on ivory imports which should significantly reduce the nation's consumption and help international efforts to protect dwindling populations of elephants. But Japan seems unlikely to follow European nations and the United States in imposing a total ban on imports (see Nature 339, 494; 1989).

Japan's Ministry of International Trade and Industry (MITI) announced last month that imports will be allowed only direct from the country of origin. As nearly 90 per cent of Japan's ivory imports last year came indirectly from suppliers in places such as Hong Kong and Singapore, many of whom are believed to have acquired the ivory illegally, the partial import ban should help to stop ivory poaching and smuggling.

Japan imports almost half of the world's hazardous organisms will require public participation, which could introduce years of delay into the licensing procedure. Drawn-out licensing procedures are one of the main justifications for pharmaceutical producers such as Hoechst and BASF pulling some research and development out of West Germany.

A struggle is brewing in Parliament about this question. The cabinet is expected to submit the law to Parliament on 12 July. The Länder (states), which are represented in the Bundesrat (upper house), are expected to push for more regulatory power. Industry supports a more central administration, with regulatory power concentrated in the ZKBS or the Health Ministry. Allowing the Länder to make their own rules regarding public participation would be "fatal", said a spokesman for the chemical industry consortium VCI

An agreement reached in the European Communities (EC)'s council of environment ministers on 8 June provided inspiration for the changes in the West German draft law. The new EC regulations (which have yet to take effect) will set minimum standards for genetic engineering research in the laboratory; standards for the release of genetically modified organisms into the environment still remain to be decided (see Nature 339, 653; 29 June 1989).

There is still a climate of strong distrust between researchers and environmentalists in West Germany, further clouding the future of molecular biology. In a recent parliamentary debate, a Green Party member demanded that all genetic engineering be banned because it could be "even more of a threat to mankind than nuclear energy".

Steven Dickman

\section{ivory trade alive}

ivory. Most of it is used to make personal seals (hanko) and plectrums for shamisen - a traditional three-string musical instrument played by geisla. The Japan General Merchandise Importers Association bemoans MITI's decision, saying it will harm Japan's traditional culture. And Japan's ivory agents sent delegates to a meeting of the Convention on the International Trade in Endangered Species (CITES) in Botswana last week to plead their case.

The Botswana meeting was held to discuss the possibility of instituting a total ban on all trade of African elephant ivory by upgrading the African elephant from Appendix 2 of CITES, which allows limited trade, to Appendix 1.

Japan is also expected to oppose a total ban when the 102 parties of CITES meet in Switzerland in October to vote on the issue. David Swinbanks

\section{Oncomouse seeks European protection} Munich

EUROPE moved one step closer to a showdown on the question of whether animals may be patented when the European Patent Office (EPO) in Munich on 28 June rejected an application to patent a transgenic mouse, known as 'oncomouse', that carries human cancer genes, or oncogenes.

But the real battle will be fought in the coming months, after European Community (EC) member states have responded to a controversial proposal from the EC executive body, the European Commission. The proposal, developed in the economics directorate of the Commission, calls for more patent protection of biotechnological discoveries, including animals and plants altered through genetic engineering. The EC Council of Ministers has begun expert hearings on the subject. West Germany and Denmark are expected to oppose the measure, and Britain will probably support it. Agreement is "not yet in sight", said Dirk Brouer of the West German Justice Ministry.

Meanwhile, the agriculture directorate of the Commission is preparing a second proposal for a new "species protection law" in the EC. The Commission has decided to wait until this proposal has been completed - it has been promised for December 1989 - before redrafting the first proposal or submitting it to the European Parliament.

Currently, the European Patent Convention, signed by 13 European countries including most $\mathrm{EC}$ members, forbids the patenting of "plant and animal varieties".

Oncomouse was developed by Harvard professor Philip Leder and Timothy Stewart, now of Genentech, and patented in April 1988 in the United States by Harvard University (see Nature 332,$668 ; 1988$ ). The patent attorney for Harvard, Paul Clark, said that there will be an appeal based on the definition of "varieties", which he claims does not rule out the patenting of transgenic animals such as the so-called oncomouse.

The decision came as no surprise to Harvard and the chemical company Du Pont, which holds exclusive rights to the US patent. In February, EPO had indicated that the application would be rejected and that EPO did not consider itself competent to decide such a crucial issue.

The case is seen as an important test for the European biotechnology industry. Should the EPO ruling eventually be overturned, it could open the door for the patenting of any species - from wheat to pigs - that has been genetically engineered. Environmentalists have defended the status quo, fearing that the granting of patents could concentrate too much power in the hands of multinational companies, to the detriment of the farmer and the developing world.
Steven Dickman 